\title{
Current clinical applications of spectral tissue Doppler echocardiography (E/E' ratio) as a noninvasive surrogate for left ventricular diastolic pressures in the diagnosis of heart failure with preserved left ventricular systolic function Stephane Arques*1, Emmanuel Roux ${ }^{1}$ and Roger Luccioni ${ }^{2}$
}

Address: ${ }^{1}$ Department of Cardiology, Aubagne Hospital, Aubagne, France and ${ }^{2}$ La Timone University of Medicine, Marseille, France Email: Stephane Arques* - sarques@ch-aubagne.fr; Emmanuel Roux - eroux@ch-aubagne.fr; Roger Luccioni - sarques@ch-aubagne.fr

* Corresponding author

Published: 26 March 2007

Cardiovascular Ultrasound 2007, 5:16 doi:10.1 |86/1476-7|20-5-16
Received: 14 March 2007

Accepted: 26 March 2007

This article is available from: http://www.cardiovascularultrasound.com/content/5/1/16

(C) 2007 Arques et al; licensee BioMed Central Ltd.

This is an Open Access article distributed under the terms of the Creative Commons Attribution License (http://creativecommons.org/licenses/by/2.0), which permits unrestricted use, distribution, and reproduction in any medium, provided the original work is properly cited.

\begin{abstract}
Congestive heart failure with preserved left ventricular systolic function has emerged as a growing epidemic medical syndrome in developed countries, which is characterized by high morbidity and mortality rates. Rapid and accurate diagnosis of this condition is essential for optimizing the therapeutic management. The diagnosis of congestive heart failure is challenging in patients presenting without obvious left ventricular systolic dysfunction and additional diagnostic information is most commonly required in this setting. Comprehensive Doppler echocardiography is the single most useful diagnostic test recommended by the ESC and ACC/AHA guidelines for assessing left ventricular ejection fraction and cardiac abnormalities in patients with suspected congestive heart failure, and non-invasively determined basal or exercise-induced pulmonary capillary hypertension is likely to become a hallmark of congestive heart failure in symptomatic patients with preserved left ventricular systolic function. The present review will focus on the current clinical applications of spectral tissue Doppler echocardiography used as a reliable noninvasive surrogate for left ventricular diastolic pressures at rest as well as during exercise in the diagnosis of heart failure with preserved left ventricular systolic function. Chronic congestive heart failure, a disease of exercise, and acute heart failure syndromes are characterized by specific pathophysiologic and diagnostic issues, and these two clinical presentations will be discussed separately.
\end{abstract}

\section{Background}

Congestive heart failure (HF) has become a highly prevalent medical syndrome in developed countries, which primarily affects older patients with a history of hypertension, coronary artery disease and diabetes mellitus [1]. There is now convincing evidence that nearly half of patients carrying a diagnosis of congestive HF do not have significant left ventricular (LV) systolic dysfunction and are referred as to suffering from HF with preserved LV systolic function (HFPSF) [2,3]. HFPSF is primarily defined as a clinical syndrome, however exercise intolerance, acute dyspnea and signs of fluid retention are nonspecific and obviously insufficient for definitely establishing the diagnosis [4-6]. The European Study Group has first proposed specific recommendations for the determination of LV diastolic dysfunction by invasive 
and noninvasive means as a diagnostic complement to the clinical syndrome in this setting [7], however, the diagnostic relevance of these additional criteria has been questioned recently [8]. Despite the absence of a large consensus [9-13], the analysis of mitral filling is currently regarded as an invaluable noninvasive tool for grading diastolic function in patients with suspected HFPSF [2]. A restrictive mitral filling pattern at Doppler echocardiography, which defines severe diastolic dysfunction and critical increase in LV filling pressures, readily identifies patients for whom symptoms are at least partly related to cardiac disease, however such a condition has been reported to account for approximately $10 \%$ of patients with HFPSF in a large, prospective population-based study [14]. Additional precision regarding LV diastolic pressures is required for the other patients to assess the severity of myocardial dysfunction and its contribution to symptoms [2]. Evidence of basal or exercise-induced pulmonary capillary hypertension is a hallmark of congestive $\mathrm{HF}$ at any level of functional disability regardless of LV systolic function [9-11], and such a marker of the severity of structural heart disease is attractive in the setting of HFPSF. Comprehensive Doppler echocardiography is currently recommended by the ESC and ACC/AHA guidelines as the single most useful diagnostic test for assessing LV ejection fraction and cardiac abnormalities in patients referred for suspected congestive HF, and non-invasively determined pulmonary capillary hypertension at rest or during exercise is likely to become a hallmark for the diagnosis of HFPSF. Our purpose is to review the current clinical applications of tissue Doppler echocardiography as a noninvasive surrogate for pulmonary capillary pressure in the diagnosis of HFPSF. Acute HF syndromes and chronic congestive HF, a disease of exercise, are characterized by specific diagnostic and prognostic issues [9-11], and these 2 clinical presentations will be discussed separately.

\section{Link between pulmonary capillary hypertension and the clinical syndrome of congestive HF: insights from hemodynamic evidence}

During exercise, pulmonary capillary pressure remains unchanged, decreases or slightly increases in healthy subjects $[15,16]$, though abnormal values $>15 \mathrm{mmHg}$ are occasionally observed for severely high degrees of exercise and cardiac output [17]. In physiological conditions, the absence of significant increase in LV diastolic pressures during exercise is partly due to cardiac and systemic adaptive mechanisms, such as increase in LV filling rate and enhancement of LV relaxation [18]. On the contrary, significant myocardial dysfunction is most commonly associated with basal or stress-induced left atrial hypertension as a consequence of maladaptive LV diastolic dynamics $[9-11,15,16,19,20]$.
According to the Starling's principles regarding fluid exchanges through the capillary wall, the fluid movement across the pulmonary capillary membrane is governed by the integrity of the capillary membrane and a balance between opposing filtrative and absorbing forces:

Fluid movement $=\mathrm{k}(\mathrm{CHP}-\mathrm{IHP})+\mathrm{k}(\pi \mathrm{if}-\pi \mathrm{c})$

Where $\mathrm{k}$ = filtration coefficient defining the fluid conductance across the capillary membrane, $\mathrm{CHP}=$ intra-capillary hydrostatic pressure, IHP = interstitial hydrostatic pressure, $\pi \mathrm{if}=$ colloid osmotic pressure of interstitial fluid and $\pi \mathrm{c}=$ plasma colloid osmotic pressure .

Landmark studies have demonstrated experimentally that pulmonary capillary hypertension is the straightforward hemodynamic condition of cardiac pulmonary edema [21-23], along with the failure of lung fluid clearance capacities to rapidly compensate the excess of fluid transudation across the capillary membrane $[24,25]$. Total pulmonary extravascular water volume is closely related to the extent and the duration of increase in pulmonary capillary pressure [21-23]. However, low plasma colloid osmotic pressure due to hypoproteinemia is likely to modulate the pulmonary capillary pressure threshold of pulmonary edema formation, a condition that may be encountered in ICU's and elderly patients with multiple co-morbidities [26-28]. This pathophysiologic model is ascribed to acute HF syndromes but it can also be applied to the setting of exercise intolerance. Reduced exercise capacity has been found to be associated with basal or stress-induced pulmonary capillary hypertension in chronic congestive $\mathrm{HF}$, irrespective of LV systolic function [16,29-31]. Sub-clinical interstitial pulmonary edema related to basal or exercise-induced pulmonary capillary hypertension is most likely to account for the reversible component of the failure of the alveolar-capillary interface [32-35], beside irreversible structural alterations such as extracellular matrix thickening and hypertrophy of the microvasculature [36]. Particularly, in a recent clinical study [35], Agricola et al have clearly established by noninvasive means the link between rest and peak-stress pulmonary capillary hypertension and basal and stressinduced interstitial pulmonary edema. In their work, Agricola et al have used ultrasound lung comets images as a reliable marker of extravascular lung water [37]. Elevated LV diastolic pressures directly contribute to reduced exercise capacity in the setting of chronic HF, along with reduced cardiac output, lung dysfunction and peripheral factors such as skeletal muscle abnormalities, deregulation of peripheral neural activity and early lactate formation $[9,16,38]$. One can therefore state that basal or stressinduced pulmonary capillary hypertension plays as a link between structural heart disease and symptoms, and noninvasive evidence of this hemodynamic condition offers 
the ability to reinforce the diagnosis of congestive HF in patients presenting with symptoms suggestive of congestive HF and normal LV ejection fraction.

\section{Reliability of spectral tissue Doppler echocardiography as a noninvasive surrogate for $L V$ diastolic pressures}

Given the limitations inherent to invasive recordings, Doppler echocardiography has become an invaluable tool for non-invasively determining LV diastolic pressures routinely. Currently, the American Society of Echocardiography recommends the use of color M-mode and spectral tissue Doppler-derived indexes, $\mathrm{E} / \mathrm{Vp}$ and $\mathrm{E} / \mathrm{E}^{\prime}$ respectively, for assessing left atrial pressure in clinical trials [39]. This is supported by a good compromise between easiness and reliability among a wide range of cardiac diseases. We will only discuss the clinical application of the E/E' ratio (see Figure 1) which has been consistently found to be more reproducible in daily practice [40].

The peak early diastolic mitral E velocity is primarily influenced by left atrial pressure, LV relaxation and LV systolic pressure in order of decreasing significance [41-43]. The spectral tissue Doppler-derived peak early diastolic E' velocity at mitral annulus is regarded as a noninvasive surrogate for $\mathrm{LV}$ relaxation, although its preload dependence has been reported in the setting of normal myocardial function [44-46]. The combination of $\mathrm{E}^{\prime}$ with peak $\mathrm{E}$ velocity (i.e., $\mathrm{E} / \mathrm{E}^{\prime}$ ratio) is assumed to overcome the influence of ventricular relaxation on peak $E$ velocity and reflect left atrial pressure, though a "pericardial constraint" effect may play a role in some patients with severely depressed LV systolic function and/or extremely high mean LV diastolic pressure [47].

Numerous clinical studies using spectral tissue Doppler for recording mitral annular velocities have produced convincing evidence of a positive, linear relation of $\mathrm{E} / \mathrm{E}$ ' with invasively determined mean LV diastolic pressure regardless of LV ejection fraction, rhythm and heart rate $[45,48$ $60]$. Some studies have also established that variations in $\mathrm{E} / \mathrm{E}^{\prime}$ accurately track changes in LV diastolic pressures under (un)loading therapy $[48,55,56]$. Clinical studies that found significant correlation between the spectral E/ $\mathrm{E}^{\prime}$ ratio and invasively determined pulmonary capillary wedge pressure or mean LV diastolic pressure in the setting of preserved LV systolic function are listed in Table 1. Tissue Doppler echocardiography is widely used for grading LV diastolic function in daily practice, particularly for differentiating the pseudonormal mitral filling pattern (which corresponds to moderate diastolic dysfunction and elevated filling pressures) from the normal filling (normal diastolic function and filling pressures) [14]. However, it appears of paramount importance to emphasize that some studies have produced convincing evidence that $\mathrm{E} / \mathrm{E}$ ' provides additional precision regarding $\mathrm{LV}$ filling pressures $[49,52]$ and diagnosis (see next paragraph) beyond the mitral filling pattern. Some limitations should be considered before interpreting tissue Doppler results: 1) Color tissue Doppler and spectral tissue Doppler are not interchangeable [61]. 2) $\mathrm{E}^{\prime}$ and $\mathrm{E} / \mathrm{E}^{\prime}$ are influenced by the mitral annular side of measurement and the level of $\mathrm{LV}$ ejection fraction [54]. 3) E/E' has been found to be more accurate than natriuretic peptides for non-invasively determining LV diastolic pressures [56]; nevertheless, E/E' allows only a semi-quantitative assessment and values of $>10,>12$ and $>11$ for lateral, septal, and average E/E', respectively, can be proposed for predicting pulmonary capillary pressure $>15 \mathrm{mmHg}$ in the presence of preserved LV systolic function [54]. 4) E/E' has been reported to be unreliable for predicting LV diastolic pressures in healthy subjects [62], organic mitral valve disease [63,64], and basal LV wall motion abnormalities related to left bundle branch block, paced-rhythm, myocardial infarction and cardiopulmonary bypass [65]. 5) E' and E/E' are influenced by age in healthy subjects [66-68]. Age-related increases in $E / E^{\prime}$ do not seem to be a consequence of higher LV diastolic pressures since left atrial pressure does not significantly rise in healthy elderly subjects $[69,70]$. Unexpected high values for $\mathrm{E} / \mathrm{E}^{\prime}$ are not uncommon in this setting, and underlying structural heart disease at comprehensive Doppler echocardiography should be taken into consideration before interpreting tissue Doppler echocardiography.

\section{Usefulness of spectral tissue Doppler echocardiography in predicting HFPSF in the setting of exercise intolerance}

Symptoms of dyspnea and fatigue usually characterize exercise intolerance in chronic congestive HF (stage $\mathrm{C}$ of the ACC/AHA classification for chronic HF) [9], regardless of LV ejection fraction [71]. Exercise intolerance correlates with maximal oxygen consumption but generally underestimate the impairment of functional capacity [72]. Preserved LV systolic function is reported to account for nearly half of patients carrying a diagnosis of congestive $\mathrm{HF}$, however 3 recent clinical studies have questioned isolated diastolic dysfunction as a frequent cause of exertional dyspnea since alternative explanations, such as obesity and respiratory diseases, are found in most patients with normal LV ejection fraction $[6,73,74]$. A recent prospective study has confirmed the lack of specificity of the symptom of exertional dyspnea for the diagnosis of congestive HF (inconclusive positive predictive value of $48 \%$ ) in a large, unselected patient group [75]. Non-invasively determined pulmonary capillary pressure at rest and during exercise is likely to be helpful for establishing the cardiac contribution to exercise intolerance, particularly among patients with confounding co-morbid conditions such as anemia, obesity and respiratory disease, which are frequently observed in this clinical setting [14]. 


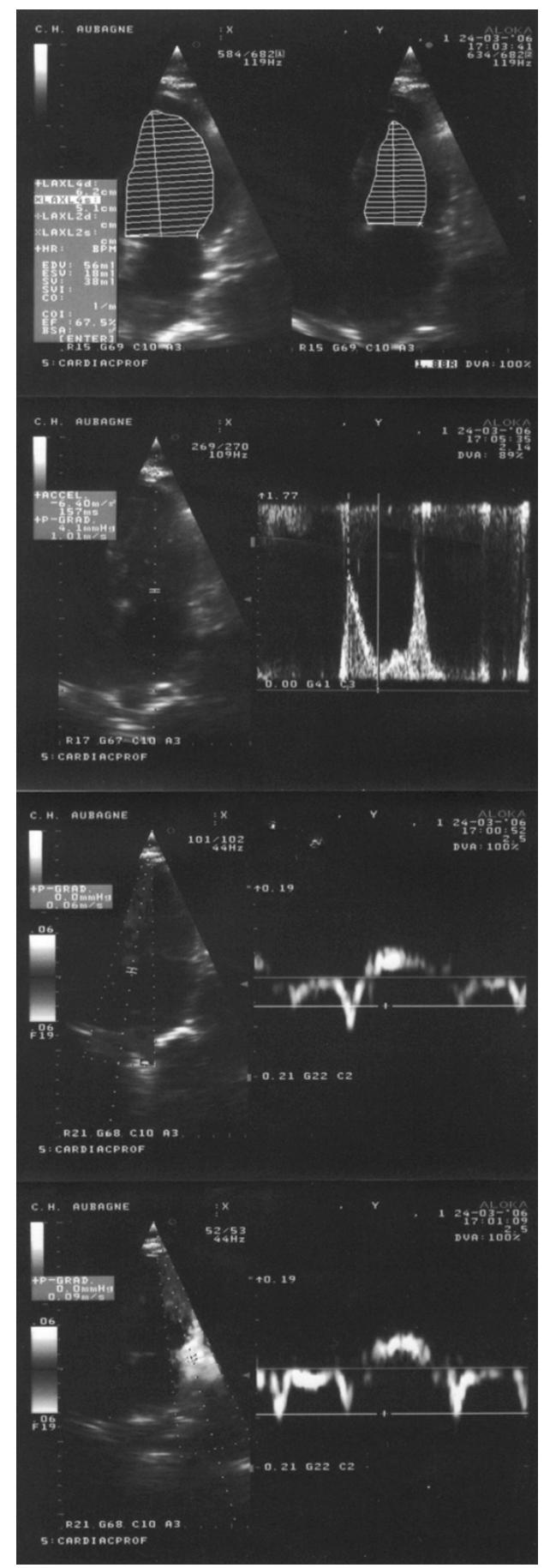

Figure I

Example of bedside measurement of spectral Doppler velocities $(\mathrm{cm} / \mathrm{s})$ in the apical 4-chamber view in a 82 years-old woman hospitalized for new-onset congestive heart failure with preserved left ventricular systolic function related to longstanding hypertension. At presentation, the score of Boston criteria was 10 and B-type natriuretic peptide concentration $460 \mathrm{pg} / \mathrm{ml}$. Bedside Doppler echocardiography performed before unloading therapy showed a left ventricular ejection fraction of $67 \%$ (upper part); peak $E$ mitral velocity between the tips of mitral leaflets was $10 \mathrm{~lm} / \mathrm{s}$, spectral tissue Doppler peak early diastolic $E^{\prime}$ velocities at the septal (middle part) and lateral corner of mitral annulus (lower part) were 6 and $9 \mathrm{~cm} / \mathrm{s}$, respectively. The patient experienced a complete relief of symptoms and signs of pulmonary congestion under unloading therapy. Invasive left ventricular end-diastolic pressure recorded after clinical stabilization was $14 \mathrm{~mm} \mathrm{Hg}$. 
Table I: Clinical studies that achieved a significant relation of spectral tissue Doppler E/E' ratio with invasive pulmonary capillary wedge pressure or mean left ventricular diastolic pressure in patients with preserved left ventricular systolic function

\begin{tabular}{|c|c|c|c|c|}
\hline Reference & Population study & Number of patients & r-value & LV ejection fraction \\
\hline Sundereswan $(1998)^{48}$ & Heart transplants & 50 & $0.8(\mathrm{~L})$ & $56 \pm 12 \%$ \\
\hline Nagueh $(1998)^{49}$ & ICU/Catheterism & 49 & $0.72(\mathrm{~L})$ & $>45 \%$ \\
\hline Nagueh $(1999)^{50}$ & $\mathrm{HCM}$ & 35 & $0.76(\mathrm{~L})$ & $>50 \%$ \\
\hline Sohn $(1999)^{51}$ & Atrial fibrillation & 27 & $0.79(\mathrm{~S})$ & $53 \pm 11 \%$ \\
\hline Ommen $(2000)^{45}$ & Catheterism & 64 & $0.47(\mathrm{~S})$ & $>50 \%$ \\
\hline $\operatorname{Kim}(2000)^{52}$ & Catheterism & 167 & $0.74(\mathrm{~S})$ & $>50 \%$ \\
\hline Gonzalez $(2002)^{53}$ & ICU & 32 & $0.54(\mathrm{~L})$ & $>50 \%$ \\
\hline Rivas-Gotz $(2003)^{54}$ & ICU/Catheterism & 55 & $0.7(\mathrm{~L})$ & $>50 \%$ \\
\hline Bruch $(2004)^{57}$ & Aortic stenosis & 23 & $0.75(S)$ & $59 \pm 11 \%$ \\
\hline Bruch $(2005)^{58}$ & Diastolic HF & 28 & $0.56(\mathrm{~A})$ & $>45 \%$ \\
\hline Hadano $(2005)^{59}$ & Catheterism & 65 & $0.54(\mathrm{~L})$ & $>50 \%$ \\
\hline Paelinck $(2005)^{60}$ & Chronic hypertension & 18 & $0.85(\mathrm{~S})$ & $58 \pm 7 \%$ \\
\hline
\end{tabular}

Catheterism: clinically indicated catheterism; HCM: hypertrophic cardiomyopathy; HF: heart failure; ICU: intensive care unit; LV: left ventricular; (L): lateral E/E' ratio; (S): septal E/E' ratio; $(A)$ : average $E / E$ ' ratio.

Exercise-induced changes in the E/E' ratio are adequately recorded in most patients. In healthy subjects, E/E' remains unchanged during exercise because of a proportional increase in $\mathrm{E}$ and $\mathrm{E}^{\prime}$ velocities [76]. It has been evidenced that $\mathrm{E} / \mathrm{E}^{\prime}$ accurately reflects changes in $\mathrm{LV}$ diastolic pressures during exercise [77,78]. Talreja et al have first reported the reliability of the septal E/E' ratio in reflecting variations of invasive $\mathrm{LV}$ diastolic pressures during exercise in 12 patients with exertional dyspnea and LV ejection fraction $>50 \%$; septal E/E' $>15$ was given to be predictive of a pulmonary capillary pressure $>20 \mathrm{~mm} \mathrm{Hg} \mathrm{[77].} \mathrm{Con-}$ firmatory findings have been later reported by Burgess et al who recorded septal E/E' and invasive mean LV diastolic pressure at rest and during exercise in 37 patients with a mean LV ejection fraction of $58 \pm 12 \%$; the regression equation was similar for resting and exercise data, E/E' > 13 indicating a mean $\mathrm{LV}$ diastolic pressure $>15 \mathrm{~mm} \mathrm{Hg}$ [78]. Several works have successfully addressed the usefulness of the spectral tissue Doppler-derived E/E' ratio at rest, as well as during exercise, in predicting peak oxygen consumption used as a hallmark of functional disability in several clinical settings [78-86]: hypertrophic cardiomyopathy, chronic systolic HF, chronic LV systolic dysfunction, permanent atrial fibrillation, coronary artery disease with preserved LV systolic function and clinically indicated treadmill exercise (see Table 2). The weak relation of $E / E^{\prime}$ with maximal oxygen consumption that is observed in unselected patient populations emphasizes the multifactorial origin of exercise intolerance in congestive HF [87].

The clinical application of diastolic stress echocardiography (i.e., the recording of $\mathrm{E} / \mathrm{E}$ ' at rest and during a symptom-limited exercise) in the setting of exertional dyspnea is relevant for establishing the cardiac contribution to symptoms. In the study by Skaluba et al in which most patients presented with a normal LV ejection fraction, septal E/E' $>10$ at rest was a strong, independent predictor of reduced exercise performance beyond LV systolic and diastolic function, as defined by the LV ejection fraction and the mitral filling pattern respectively [86]. In the study by Ha et al which focused on 45 patients with exertional dyspnea and normal LV ejection fraction, exercise duration was significantly less in patients with septal E/E' $>10$ at rest or at peak exercise $(7.1 \pm 3.3$ and $7.2 \pm 2.5$ minutes, respectively) compared to patients with septal E/E' < 10 both at rest and peak exercise $(10.4 \pm 3.7$ minutes, $\mathrm{p}=$ $0.01)$ [88]. Confirmatory findings were reported by Burgess et al in a large patient population with preserved $\mathrm{LV}$ systolic function; particularly, exercise capacity was significantly less in patients with mild diastolic dysfunction and abnormal post-exercise septal E/E' (>10) compared with those with mild diastolic dysfunction but without abnormal post-exercise value for $\mathrm{E} / \mathrm{E}^{\prime}(7 \pm 2.5$ vs. $9.6 \pm 2.6 \mathrm{METs}$ respectively, $\mathrm{p}<0.01$ ) [78]. Septal E/E' > 10 measured at rest, at peak stress or immediately after exercise reinforces the likelihood that myocardial dysfunction (i.e., isolated diastolic dysfunction in the setting of normal LV ejection fraction and volumes) directly contributes to exertional symptoms, and may be very helpful for establishing the diagnosis of HFPSF (see Figure 2), along with other variables such as restrictive mitral filling pattern and increased natriuretic peptides concentrations $[9,10,14]$. Establishing underlying structural heart disease by comprehensive Doppler echocardiography is a necessary prerequisite before interpreting diastolic stress echocardiography (see Table 3), since values of $10-15$ for septal E/E' are not uncommon in healthy elderly subjects [67]. The use of 
Table 2: Clinical studies that investigated the relation of the spectral tissue Doppler E/E' ratio with maximal exercise tolerance

\begin{tabular}{|c|c|c|c|c|}
\hline Reference & Population study & $\begin{array}{l}\text { Number of } \\
\text { patients }\end{array}$ & Relation with PVo2 & $\begin{array}{l}\text { Spectral tissue Doppler index } \\
\text { measured at rest }\end{array}$ \\
\hline Matsumura 79 & HCM & 85 & $-0.42 *(p<0.001)$ & Lateral E/E' ratio \\
\hline McMahon 80 & HCM in children & 80 & $-0.74 *(p<0.001)$ & Septal E/E' ratio \\
\hline $\mathrm{Ha}^{81}$ & $\mathrm{HCM}$ & 29 & $-0.47 *(p=0.01)$ & Septal E/E' ratio \\
\hline Smart ${ }^{82}$ & Chronic systolic HF & 95 & $-0.31 *(p=0.00 I)$ & Average $E / E^{\prime}$ ratio \\
\hline $\operatorname{Lee}^{83}$ & Permanent atrial fibrillation & 73 & $-0.35 t(p=0.03)$ & Septal E/E' ratio \\
\hline Hadano 84 & $\begin{array}{c}\text { Chronic LV systolic } \\
\text { dysfunction }\end{array}$ & 53 & $-0.68 *(p<0.001)$ & Lateral E/E' ratio \\
\hline Van de Veire ${ }^{85}$ & $\begin{array}{l}\text { CAD and preserved LV } \\
\text { systolic function }\end{array}$ & 142 & $P=0.005 \ddagger$ & Septal E/E' ratio \\
\hline Reference & Population study & $\begin{array}{l}\text { Number of } \\
\text { patients }\end{array}$ & Relation with METs & $\begin{array}{c}\text { Spectral tissue Doppler index } \\
\text { measured at rest }\end{array}$ \\
\hline Skaluba ${ }^{86}$ & $\begin{array}{l}\text { Clinically indicated } \\
\text { treadmill exercise }\end{array}$ & 121 & $-0.68 *(p<0.001)$ & Septal E/E' ratio \\
\hline Burgess $^{78}$ & $\begin{array}{l}\text { Clinically indicated } \\
\text { treadmill exercise }\end{array}$ & 166 & $-0.37 *(p<0.001)$ & Septal E/E' ratio \\
\hline Reference & Population study & $\begin{array}{l}\text { Number of } \\
\text { patients }\end{array}$ & Relation with METs & $\begin{array}{c}\text { Post-exercise spectral tissue } \\
\text { Doppler index }\end{array}$ \\
\hline Burgess $^{78}$ & $\begin{array}{l}\text { Clinically indicated } \\
\text { treadmill exercise }\end{array}$ & 166 & $-0.44 *(p<0.001)$ & Septal E/E' ratio \\
\hline
\end{tabular}

CAD: coronary artery disease; HCM: hypertrophic cardiomyopathy; HF: heart failure; LV: left ventricular; METs: achieved metabolic equivalents; PVo2: peak oxygen consumption during exercise.

*: univariate regression analysis; t: multivariate regression analysis; ‡: analysis of variance for E/E' between quartiles of PVo2.

higher cut-off values (13 to 15 ) would reinforce the positive predictive value but would lack the negative predictive value of that test [78].

\section{Usefulness of bedside spectral tissue Doppler echocardiography in the emergency diagnosis of acute HFPSF}

Acute, transient exacerbation of symptoms is a common clinical presentation of HFPSF, particularly among elderly patients [3]. The clinical diagnosis of acute HF syndromes is challenging in the emergency care setting [5]. In the landmark "Breathing not Properly Multinational" study, the Framingham score was reported to be $85 \%$ sensitive and $58 \%$ specific for the clinical diagnosis of congestive $\mathrm{HF}$ in a large, unselected patient population presenting with acute dyspnea [89]. Therefore, additional diagnostic methods are required in this clinical setting to accurately establish the diagnosis of acute congestive HF. The brain natriuretic peptide (BNP), a cardiac neurohormone that is secreted in response to myocardial stretch and volume overload, has been validated as a powerful and cost-effective diagnostic marker of congestive HF [90], and is extensively utilized as the first-line diagnostic complement to clinical and radiographic data in the acute care setting. A BNP level of $<100 \mathrm{pg} / \mathrm{ml}$ in sinus rhythm and $<200 \mathrm{pg} /$ $\mathrm{ml}$ in arrhythmia is helpful for excluding the diagnosis of congestive HF with a likelihood of $>90 \%$; conversely, a $\mathrm{BNP}$ value of $>400-500 \mathrm{pg} / \mathrm{ml}$ readily identifies congestive HF with a positive predictive value of $90 \%[90,91]$. Nevertheless, this biomarker is reported to be nondiag-

Table 3: Abnormalities at comprehensive Doppler echocardiography suggestive of structural heart disease without evidence of overt left ventricular systolic dysfunction and/or basal pulmonary capillary hypertension

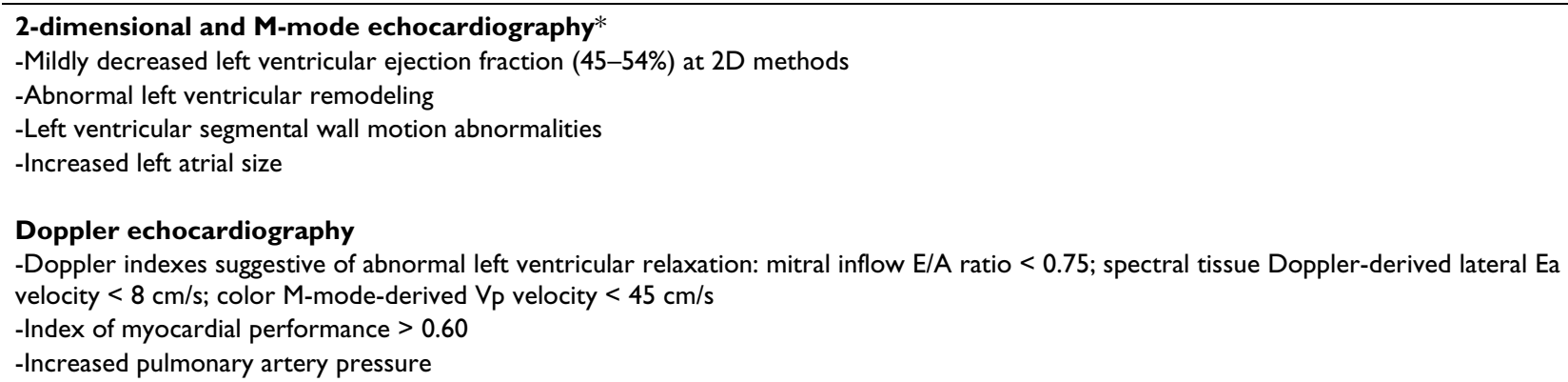

*: for more information, report to the ASE Committee Recommendations. Lang RM, et al. J Am Soc Echocardiogr 2005; I8: I440-I463. 


\section{Dyspnea on exertion}

\section{Structural heart disease at comprehensive \\ Doppler echocardiography \\ $+\mathrm{LV}$ ejection fraction $>50 \%$}

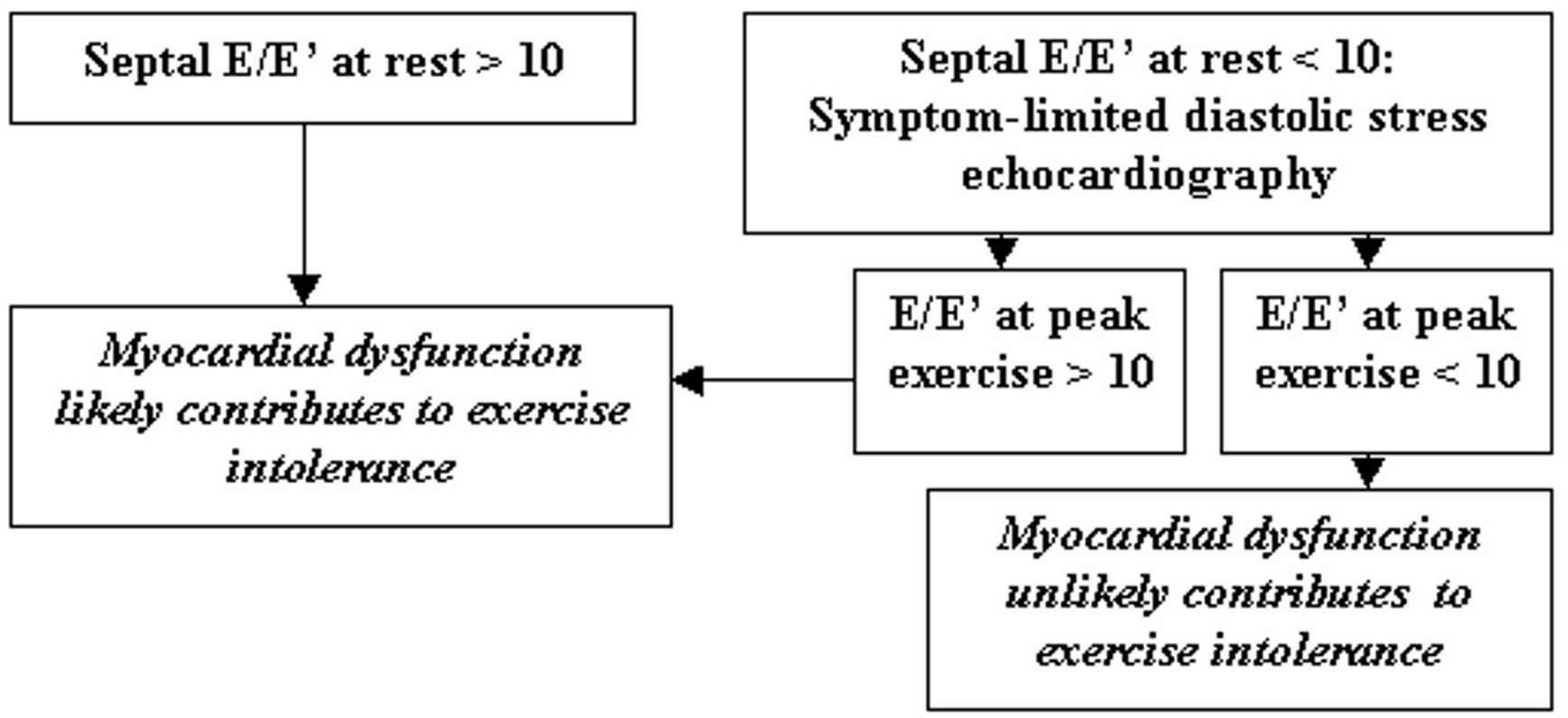

Figure 2

Proposition for a simplified diagnostic algorithm regarding the contribution of tissue Doppler echocardiography to the diagnosis of chronic heart failure with preserved left ventricular systolic function (stage $C$ of the ACC/AHA classification) in patients presenting with exertional dyspnea, after excluding overt myocardial ischemia, significant valvular disease and arrhythmias; adapted from the references [9,67,76-78,88]. E: peak E mitral velocity; E': spectral tissue Doppler peak early diastolic velocity at the septal side of mitral annulus; LV: left ventricular. The use of a cut-off value of 13 would reinforce the positive predictive value but would lack the negative predictive value.

nostic at levels in the middle range (100-500 pg/ml) [90], and discrepant with the clinical judgment in a significant proportion of cases. Bedside Doppler echocardiography may ideally take place in the diagnostic strategy for such patients, particularly those with severe symptoms who experience a worse short-term outcome and require a rapid and accurate diagnosis for early improving the therapeutic care $[90,92,93]$.

An echocardiographic LV ejection fraction of $<40-45 \%$ has been reported to be a powerful predictor of cardiac origin in patients presenting with acute dyspnea $[89,94]$. In the study by Logeart et al which focused on patients hospitalized for acute severe dyspnea, only 7 of the 82 patients with a bedside LV ejection fraction $<45 \%$ at presentation were classified having noncardiac cause of acute dyspnea at discharge [94]. In the "Breathing not Properly Multinational" study, LV ejection fraction was reported to have a positive predictive value of 88 and $94 \%$ at respective levels of $\leq 50 \%$ and $\leq 40 \%$ for the diagnosis of congestive HF in the setting of acute dyspnea [89].

Noninvasive assessment of LV diastolic pressures at presentation, before tailored therapy, is clinically relevant particularly for patients with severe symptoms, inconclusive clinical, radiographic and biochemical data and preserved LV ejection fraction at echocardiography (see Table 4). It appears of paramount importance to emphasize that recordings after clinical stabilization may lead to inconclusive resting tissue Doppler results in patients for whom a positive response of pulmonary capillary hypertension has been reached under unloading therapy $[95,96]$. 
Table 4: Clinical studies that investigated the accuracy of the spectral tissue Doppler E/E' for the diagnosis of acute congestive heart failure on admission before tailored therapy.

\begin{tabular}{|c|c|c|c|c|}
\hline Reference & Population study & $\begin{array}{l}\text { Number of } \\
\text { patients }\end{array}$ & Sensitivity-Specificity & Threshold value for E/E' \\
\hline Dokainish 97 & $\begin{array}{l}\text { NYHA II to IV } \\
\text { LVEF }<50 \%\end{array}$ & 76 & $92 \%-72 \%$ & Average $E / E^{\prime}>15$ \\
\hline Dokainish 97 & $\begin{array}{l}\text { NYHA II to IV } \\
\text { LVEF > 50\% }\end{array}$ & 46 & $79 \%-93 \%$ & Average E/E' > 15 \\
\hline Arques ${ }^{98}$ & $\begin{array}{c}\text { Acute dyspnea at rest } \\
\text { LVEF }>45 \%\end{array}$ & 70 & $\begin{array}{c}80 \%-94.3 \% \\
76.7 \%-91.4 \%\end{array}$ & $\begin{array}{c}\text { Average } E / E^{\prime}>11.5 \\
\text { Septal } E / E^{\prime}>13\end{array}$ \\
\hline Arques 99 & $\begin{array}{l}\text { Acute dyspnea at rest } \\
\text { LVEF }>50 \% \text {, BNP 100-400 pg/ml }\end{array}$ & 34 & $\begin{array}{l}88.2 \%-76.5 \% \\
76.5 \%-88.2 \%\end{array}$ & $\begin{array}{c}\text { Average } E / E^{\prime}>10.1 \\
\text { Septal E/E' }>13\end{array}$ \\
\hline Arques 100 & $\begin{array}{l}\text { Acute dyspnea at rest, elderly } \\
\text { LVEF > } 50 \% \text {, atrial fibrillation }\end{array}$ & 41 & $81.8 \%-89.5 \%$ & Septal E/E' > 13 \\
\hline Arques 104 & $\begin{array}{l}\text { Acute dyspnea } \\
\text { LVEF }>50 \% \text {, hypertension }\end{array}$ & 40 & $77.8 \%-100 \%$ & Lateral E/E' > II \\
\hline Huang 105 & $\begin{array}{l}\text { Acute dyspnea } \\
\text { LVEF }<50 \%\end{array}$ & $-*$ & $70.8 \%-100 \%$ & Average $E / E^{\prime}>16$ \\
\hline Huang 105 & $\begin{array}{l}\text { Acute dyspnea } \\
\text { LVEF > 50\% }\end{array}$ & $-*$ & $88.9 \%-82.9 \%$ & Average E/E' > II \\
\hline
\end{tabular}

BNP: B-type natriuretic peptide; LVEF: left ventricular ejection fraction;*: overall population of 92 patients.

Dokainish et al have first reported the diagnostic accuracy of tissue Doppler echocardiography in a large patient population referred for suspected congestive HF with a wide range of symptoms (NYHA class II to IV) and LV ejection fractions [97]. The diagnostic accuracy of E/E' was similar to BNP regardless of LV ejection fraction; furthermore, these 2 methods were able to provide independent diagnostic information, supporting their complementary role in this setting. Three recent works have specifically addressed the usefulness of bedside tissue Doppler echocardiography as well as its incremental role over the clinical judgment and BNP testing in the emergency diagnosis of acute HFPSF in patients hospitalized for acute severe dyspnea; this noninvasive method was found to be accurate, even among patients with inconclusive BNP levels $(100-400 \mathrm{pg} / \mathrm{ml})$ or arrhythmia [98-100]. In these 3 studies, the clinical judgment of HF was based on the presence of prior history of congestive HF and/or radiographic evidence of pulmonary edema, 2 simple criteria that are among the most powerful predictors of congestive HF in the acute setting [5,101-103]; standard cut-off values for BNP in sinus rhythm $(100 \mathrm{pg} / \mathrm{ml})$ and permanent atrial fibrillation $(200 \mathrm{pg} / \mathrm{ml})$ were also utilized [91]. As expected, the agreement between the clinical judgment and BNP concentration achieved high accuracy for the etiologic diagnosis, and septal E/E' at a cut-off value of 13 correctly classified more than $85 \%$ of patients with discrepancy [98-100]. Septal E/E' at the cut-off value of 13 offers the ability to establish the diagnosis of congestive HF with a sensitivity of $76-82 \%$ and a specificity of $88-$ $91 \%$ in the setting of acute dyspnea and preserved LV systolic function [98-100], however its combination with the clinical judgment and BNP testing (which plays as a marker of "chronic" filling pressures) may be more rele- vant to overcome the potential influence of low serum protein concentration in ICU's and elderly patients and to track false negatives due to transient increases in LV diastolic pressures (see Figure 3) [28,100]. Furthermore, along with tissue Doppler echocardiography, evidence of a restrictive mitral filling pattern reinforces the likelihood of acute congestive HF in this setting $[94,99]$. Bedside tissue Doppler echocardiography has been confirmed to be useful for the emergency diagnosis of acute HFPSF in patients with longstanding hypertension, achieving a better reproducibility and accuracy than the color M-mode Doppler-derived E/Vp ratio in this setting [104]. Another clinical study has provided confirmatory findings regarding the accuracy of tissue Doppler echocardiography for the diagnosis of acute congestive HF as well as its incremental role over inconclusive BNP levels in a small patient population with a wide range of $\mathrm{LV}$ ejection fractions [105].

\section{Conclusion}

According to the ACC/AHA recommendations, the diagnosis of congestive HF is defined by the association of structural heart disease with symptoms compatible with the diagnosis. In the light of the present review, we can state that tissue Doppler evidence of pulmonary capillary hypertension at rest and unmasked during exercise is likely to become a hallmark for the diagnosis of congestive HF in the setting of preserved LV systolic function, regardless of the clinical presentation.

\section{Competing interests}

financial competing interests

None 


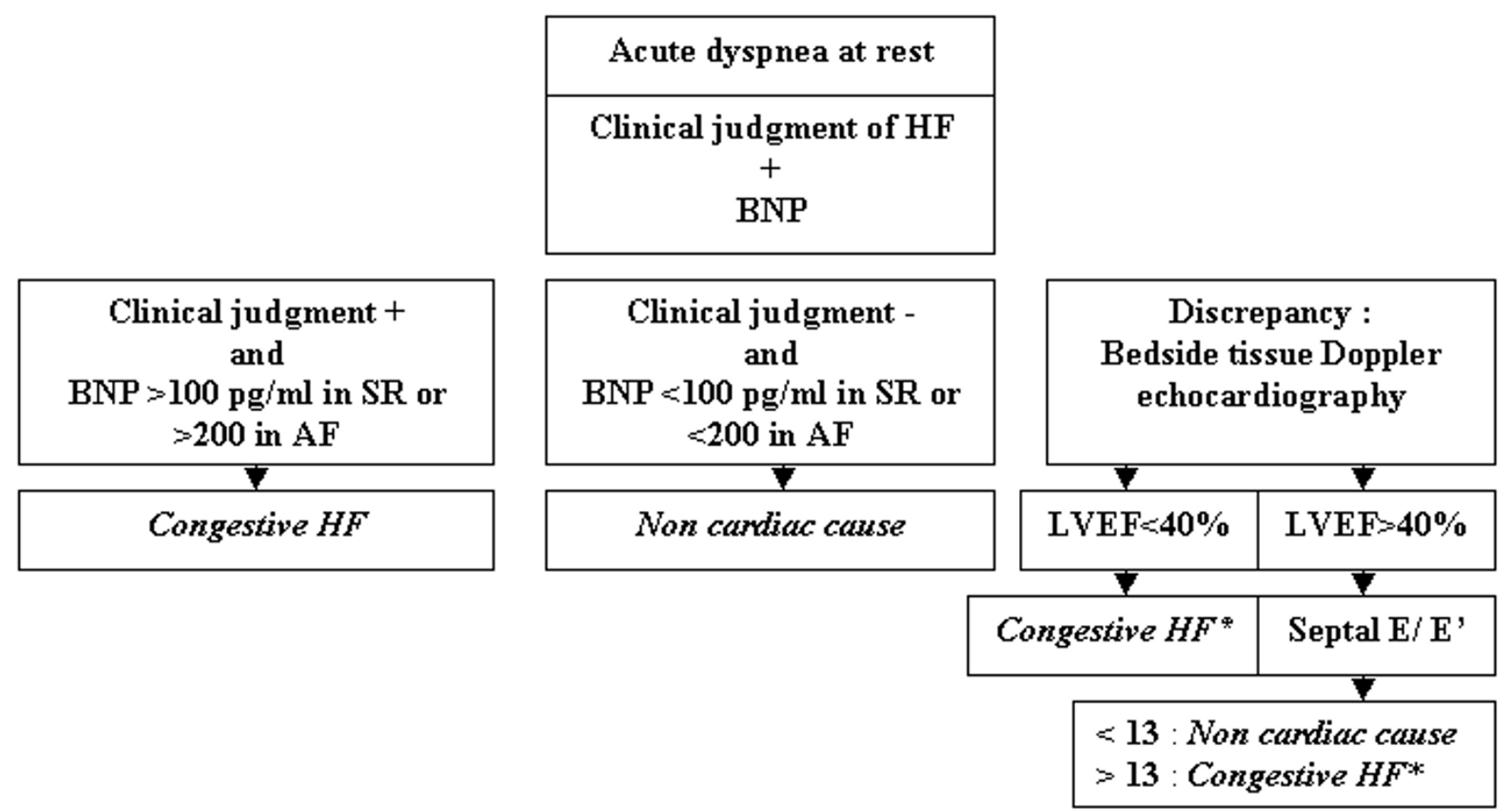

Figure 3

Proposition for a simplified diagnostic algorithm in the emergency diagnosis of acute congestive heart failure on admission, before tailored therapy, in patients presenting with acute dyspnea; adapted from references [5,89,9I,94,98-I02]. AF: atrial fibrillation; BNP: B-type natriuretic peptide; E: peak E mitral velocity; E': peak early diastolic velocity by spectral tissue Doppler at the septal side of mitral annulus; HF: heart failure; LVEF: left ventricular ejection fraction; SR: sinus rhythm. The clinical judgment of heart failure is based on the presence of prior history of heart failure and/or radiographic pulmonary edema. *: evidence of a restrictive mitral filling pattern reinforces the likelihood of acute congestive HF.

Non-financial competing interests

None

\section{References}

I. Owan TE, Hodge DO, Herges RM, Jacobsen RJ, Roger VL, Redfield MM: Trends in prevalence and outcome of heart failure with preserved ejection fraction. New Engl J Med 2006, 355:25I-259.

2. Galderisi M: Diastolic dysfunction and diastolic heart failure: diagnostic, prognostic and therapeutic aspects. Cardiovasc Ultrasound 2005, 3:9.

3. Banerjee P, Clark AL, Nikitin N, Cleland JG: Diastolic heart failure. Paroxysmal or chronic? Eur J Heart Fail 2004, 6:427-43I

4. Remes J, Miettinen H, Reunanen A, Pyorala K: Validity of clinical diagnosis of heart failure in primary health care. Eur Heart J |99|, I 2:3|5-32|.

5. Wang CS, FitzGerald JM, Schulzer M, Mak E, Ayas NT: Does this dyspneic patient in the emergency department have congestive heart failure? JAMA 2005, 294:1944-1956.

6. Caruana L, Petrie MC, Davie AP, McMurray J]: Do patients with suspected heart failure and preserved left ventricular systolic function suffer from "diastolic heart failure" or from misdiagnosis? A prospective descriptive study. BMJ 2000, 321:215-218.

7. How to diagnose diastolic heart failure. European Study Group on Diastolic heart Failure. Eur Heart J 1998, 1 9:990- 1003.

8. Cahill JM, Horan M, Quigley P, Maurer B, McDonald K: Dopplerechocardiographic indices of diastolic function in heart fail- ure admissions with preserved left ventricular systolic function. Eur J Heart Fail 2002, 4:473-478.

9. Hunt SA, Abraham WT, Chin MH: ACCIAHA 2005 Guideline Update for the Diagnosis and Management of Chronic Heart Failure in the Adult: a report of the American College of Cardiology/American Heart Association Task Force on Practice Guidelines (Writing Committee to Update the 200 I Guidelines for the Evaluation and Management of Heart Failure): developed in collaboration with the American College of Chest Physicians and the International Society for Heart and Lung Transplantation: endorsed by the Heart Rhythm Society. Circulation 2005, I I 2:e I54-e235.

10. Swedberg K, Cleland J, Dargie H: Task Force for the Diagnosis and Treatment of Chronic Heart Failure of the European Society of Cardiology. Guidelines for the diagnosis and treatment of chronic heart failure: executive summary (update 2005): The Task Force for the Diagnosis and Treatment of Chronic Heart Failure of the European Society of Cardiology. Eur Heart ] 2005, 26: I I I5- I I 40.

II. Nieminen MS, Bohm M, Cowie MR: Executive summary of the guidelines on the diagnosis and treatment of acute heart failure: the Task Force on Acute Heart Failure of the European Society of Cardiology. Eur Heart J 2005, 26:384-4I6.

12. Maurer MS, Spevack D, Burkhoff D, Kronzon I: Diastolic dysfunction: can it be diagnosed by Doppler echocardiography? I Am Coll Cardiol 2004, 44: I543-I 549.

13. Oh JK, Hatle L, Tajik AJ, Little WC: Diastolic heart failure can be diagnosed by comprehensive two-dimensional and Doppler echocardiography. J Am Coll Cardiol 2006, 47:500-506.

14. Bursi F, Weston SA, Redfield MM: Systolic and diastolic heart failure in the community. JAMA 2006, 296:2209-22I6. 
15. Okada RD, Osbakken MD, Boucher CA, Strauss HW, Block PC, Pohost GM: Pulmonary blood volume ratio response to exercise; a noninvasive determination of exercise-induced changes in pulmonary capillary wedge pressure. Circulation 1982, 65:126-133.

16. Kitzman DW, Higginbotham MB, Cobb FR, Sheikh KH, Sullivan MJ: Exercise intolerance in patients with heart failure and preserved left ventricular systolic function: failure of the FrankStarling mechanism. J Am Coll Cardiol I991, I 7:1065-1072.

17. Reeves JT, Linehan JH, Stenmark KR: Distensibility of the normal human lung circulation during exercise. Am J Physiol Lung Cell Moll Physiol 2005, 288:L419-L425.

18. Cheng CP, Igarashi Y, Little WC: Mechanisms of augmented rate of left ventricular filling during exercise. Circ Res 1992, 70:9-19.

19. Cheng CP, Noda T, Nozawa T, Little WC: Effect of heart failure on the mechanism of exercise-induced augmentation of mitral valve flow. Circ Res 1993, 72:795-806.

20. Faggiano P, D'Aloia A, Gualeni A, Giordano A: Hemodynamic profile of submaximal constant workload exercise in patients with heart failure secondary to ischemic or idiopathic dilated cardiomyopathy. Am J Cardiol 1998, 8 I:437-442.

21. Guyton AC, Lindsey AW: Effect of elevated left atrial pressure and decreased plasma protein concentration on the development of pulmonary edema. Circ Res 1959, 7:649-657.

22. Gaar KA Jr, Taylor AE, Owens LJ, Guyton AC: Effect of capillary pressure and plasma protein on development of pulmonary edema. Am J Physiol 1967, 2 I 3:79-82.

23. Levine OR, Mellins RB, Senior RM, Fishman AP: The application of Starling's law of capillary exchange to the lungs. J Clin Invest 1967, 46:934-944.

24. Verghese GM, Ware LB, Matthay BA, Matthay MA: Alveolar epithelial fluid transport and the resolution of clinically severe hydrostatic pulmonary edema. I Appl Physiol 1999, 87: $1301-1312$

25. Berthiaume $\mathrm{Y}$, Folkesson HG, Matthay MA: Lung edema clearance: $\mathbf{2 0}$ years of progress: invited review: alveolar edema fluid clearance in the injured lung. I Appl Physiol 2002, 93:2207-2213.

26. Rackow EC, Fein IA, Siegel J: The relationship of the colloid osmotic-pulmonary artery wedge pressure gradient to pulmonary edema and mortality in critically ill patients. Chest 1982, 82:433-437.

27. Arques S, Ambrosi P, Gelisse R, Luccioni R, Habib G: Hypoalbuminemia in elderly patients with acute diastolic heart failure. I Am Coll Cardiol 2003, 42:712-716.

28. Arques S, Roux E, Sbragia P, Ambrosi P, Pieri B, Gelisse R, Luccioni R: B-type natriuretic peptide and tissue Doppler study findings in elderly patients hospitalized for acute diastolic heart failure. Am J Cardiol 2005, 96:104-107.

29. Nanas S, Nanas J, Papazachou O, Kassiotis C, Papamichalopoulos A, Milic-Emili J, Roussos C: Resting lung function and hemodynamic parameters as predictors of exercise capacity in patients with chronic heart failure. Chest 2003, 1 23: | 386-1393.

30. Sutcliffe PD, Aaronson KD, Cody RJ, Koelling TM: Impact of serial changes in cardiac hemodynamics on exercise performance in patients with heart failure due to ischemic and nonischemic cardiomyopathy. Am J Cardiol 2003, 91: I64-I68.

31. Tschope C, Kasner M, Westermann D, Walther T, Gaub R, Poller WC, Schultheiss HP: Elevated NT-ProBNP levels in patients with increased left ventricular filling pressure during exercise despite preserved systolic function. J Card Fail 2005, I I (5 suppl):S28-S33.

32. Chomsky DB, Lang CC, Rayos G, Wilson JR: Treatment of subclinical fluid retention in patients with symptomatic heart failure: effect on exercise performance. J Heart Lung Transplant 1997, 1 6:846-853.

33. Puri S, Dutka DP, Baker BL, Hughes JM, Cleland JG: Acute saline infusion reduces alveolar-capillary membrane conductance and increases airflow obstruction in patients with left ventricular dysfunction. Circulation 1999, 99: I 190- I 196.

34. Agostoni P, Cattadori G, Bianchi M, Wasserman K: Exerciseinduced pulmonary edema in heart failure. Circulation 2003, [ 08:2666-267].

35. Agricola E, Picano E, Oppizzi M, Pisani M, Meris A, Fragasso G, Margonato A: Assessment of stress-induced pulmonary interstitial edema by chest ultrasound during exercise echocardiogra- phy and its correlation with left ventricular function. J Am Soc Echocardiogr 2006, 19:457-463.

36. Guazzi M: Alveolar-capillary membrane dysfunction in heart failure: evidence of a pathophysiologic role. Chest 2003, 1 24: 1090-I I02

37. Picano E, Frassi F, Agricola E, Gligorova S, Gargani L, Mottola G: Ultrasound lung comets: a clinically useful sign of extravascular lung water. J Am Soc Echocardiogr 2006, 19:356-363.

38. Kraemer MD, Kubo SH, Rector TS, Brunsvold N, Bank Al: Pulmonary and peripheral vascular factors are important determinants of peak exercise oxygen uptake in patients with heart failure. J Am Coll Cardiol 1993, 21:641-648.

39. Gottdiener JS, Bednarz J, Devereux R: American Society of Echocardiography. American Society of Echocardiography recommendations for use of echocardiography in clinical trials. J Am Soc Echocardiogr 2004, I 7: 1086- I I 19.

40. Bess RL, Khan S, Rosman HS, Cohen GI, Allebban Z, Gardin JM: Technical aspects of diastology: why mitral inflow and tissue Doppler imaging are the preferred parameters? Echocardiography 2006, 23:332-339.

4I. Ishida Y, Meisner JS, Tsujioka K, Gallo Jl, Yoran C, Frater RW, Yellin EL: Left ventricular filling dynamics: influence of left ventricular relaxation and left atrial pressure. Circulation 1986, 74:187-196.

42. Choong CY, Abascal VM, Thomas JD, Guerrero JL, McGlew S, Weyman AE: Combined influence of ventricular loading and relaxation on the transmitral flow velocity profile in dogs measured by Doppler echocardiography. Circulation 1988, 78:672-683.

43. Thomas JD, Choong CY, Flachskampf FA, Weyman AE: Analysis of the early transmitral Doppler velocity curve: effect of primary physiologic changes and compensatory preload adjustment. J Am Coll Cardiol 1990, 16:644-655.

44. Sohn DW, Chai IH, Lee DJ, Kim HC, Kim HS, Oh BH, Lee MM, Park YB, Choi YS, Seo JD, Lee YW: Assessment of mitral annulus velocity by Doppler tissue imaging in the evaluation of left ventricular diastolic function. I Am Coll Cardiol I997, 30:474-480.

45. Ommen SR, Nishimura RA, Appleton CP, Miller FA, Oh JK, Redfield MM, Tajik AJ: Clinical utility of Doppler echocardiography and tissue Doppler imaging in the estimation of left ventricular filling pressures: A comparative simultaneous Doppler-catheterization study. Circulation 2000, 1 02:1788-1794.

46. Nagueh SF, Sun H, Kopelen HA, Middleton KJ, Khoury DS: Hemodynamic determinants of the mitral annulus diastolic velocities by tissue Doppler. J Am Coll Cardiol 200I, 37:278-285.

47. Arques S: Usefulness of combined Doppler indexes in predicting left ventricular filling pressures in patients with acute heart failure. Am / Cardiol 2003, 92:649-650.

48. Sundereswaran L, Nagueh SF, Vardan S, Middleton KJ, Zoghbi WA, Quinones MA, Torre-Amione G: Estimation of left and right ventricular filling pressures after heart transplantation by tissue Doppler imaging. Am J Cardiol 1998, 82:352-357.

49. Nagueh SF, Mikati I, Kopelen HA, Middleton KJ, Quinones MA, Zoghbi WA: Doppler estimation of left ventricular filling pressure in sinus tachycardia. A new application of tissue doppler imaging. Circulation 1998, 98:1644-1650.

50. Nagueh SF, Lakkis NM, Midleton KJ, Spencer WH 3rd, Zoghbi WA, Quinones MA: Doppler estimation of left ventricular filling pressures in patients with hypertrophic cardiomyopathy. Circulation 1999, 99:254-26I.

5I. Sohn DW, Song JM, Zo JH, Chai IH, Kim HS, Chun HG, Kim HC: Mitral annulus velocity in the evaluation of left ventricular diastolic function in atrial fibrillation. J Am Soc Echocardiogr 1999, I 2:927-931.

52. Kim YJ, Sohn DW: Mitral annulus velocity in the estimation of left ventricular filling pressure: prospective study in 200 patients. I Am Soc Echocardiogr 2000, I 3:980-985.

53. Gonzalez-Vilchez F, Ayuela J, Ares M, Mata NS, Gonzalez AG, Duran RM: Comparison of Doppler echocardiography, color $M$ mode Doppler, and Doppler tissue imaging for the estimation of pulmonary capillary wedge pressure. J Am Soc Echocardiogr 2002, I 5: I 245-I250.

54. Rivas-Gotz C, Manolios M, Thohan V, Nagueh SF: Impact of left ventricular ejection fraction on estimation of left ventricular filling pressures using tissue Doppler and flow propagation velocity. Am J Cardiol 2003, 9 I:780-784. 
55. Bouhemad B, Nicolas-Robin A, Benois A, Lemaire S, Goarin JP, Rouby J]: Echocardiographic Doppler assessment of pulmonary capillary pressure in surgical patients with postoperative circulatory shock and acute lung injury. Anesthesiology 2003, 98:1091-1100

56. Dokainish H, Zoghbi WA, Lakkis NM, Al-Bakshy F, Dhir M, Quinones MA, Nagueh SF: Optimal noninvasive assessment of left ventricular filling pressures. A comparison of tissue Doppler echocardiography and B-type natriuretic peptide in patients with pulmonary artery catheters. Circulation 2004, 109:2432-2439.

57. Bruch C, Stypmann J, Grude M, Gradaus R, Breithardt G, Wichter T: Tissue Doppler imaging in patients with moderate to severe aortic valve stenosis: clinical usefulness and diagnostic accuracy. Am Heart J 2004, I 48:696-702.

58. Bruch C, Grude M, Muller J, Breithardt G, Wichter T: Usefulness of tissue Doppler imaging for estimation of left ventricular filling pressures in patients with systolic and diastolic heart failure. Am J Cardiol 2005, 95:892-895.

59. Hadano Y, Murata K, Liu J, Oyama R, Harada N, Okuda S, Hamada Y, Tanaka N, Matsuzaki M: Can transthoracic Doppler echocardiography predict the discrepancy between left ventricular end-diastolic pressure and mean pulmonary capillary wedge pressure in patients with heart failure? Circ J 2005, 69:432-438.

60. Paelinck BP, de Roos A, Bax JJ, Bosmans JM, van Der Geest RJ, Dhondt D, Parizel PM, Vrints CJ, Lamb HJ: Feasibility of tissue magnetic resonance imaging: a pilot study in comparison with tissue Doppler imaging and invasive measurement. J Am Coll Cardiol 2005, 45: I 109-III6.

61. McCulloch M, Zoghbi WA, Davis R, Thomas C, Dokainish H: Color tissue Doppler myocardial velocities consistently underestimate spectral tissue Doppler velocities: impact on calculation peak transmitral pulsed Doppler velocity/early diastolic tissue Doppler velocity (E/Ea). J Am Soc Echocardiogr 2006, 19:744-748.

62. Firstenberg MS, Levine BD, Garcia MJ, Greenberg NL, Cardon L, Morehead AJ, Zuckerman J, Thomas JD: Relationship of echocardiographic indices to pulmonary capillary wedge pressures in healthy volunteers. J Am Coll Cardiol 2000, 36:1664-1669.

63. Bruch C, Stypmann J, Gradaus R, Breithardt G, Wichter T: Usefulness of tissue Doppler imaging for estimation of filling pressures in patients with primary or secondary pure mitral regurgitation. Am J Cardiol 2004, 93:324-328.

64. Diwan A, McCulloch M, Lawrie GM, Reardon MJ, Nagueh SF: Doppler estimation of left ventricular filling pressures in patients with mitral valve disease. Circulation 2005, I I I:328I-3289.

65. D'Souza KA, Mooney DJ, Russell AE, Maclsaac AI, Aylward PE, Prior $\mathrm{DL}$ : Abnormal septal motion affects early diastolic velocities at the septal and lateral mitral annulus, and impacts on estimation of the pulmonary capillary wedge pressure. J Am Soc Echocardiogr 2005, 18:445-453.

66. Tighe DA, Vinch CS, Hill JC, Meyer TE, Goldberg RJ, Aurigemma GP: Influence of age on assessment of diastolic function by Doppler tissue imaging. Am J Cardiol 2003, 9 I:254-257.

67. Munagala VK, Jacobsen SJ, Mahoney DW, Rodeheffer RJ, Bailey KR, Redfield MM: Association of newer diastolic function parameters with age in healthy subjects: a population-based study. J Am Soc Echocardiogr 2003, 16:1049-1056.

68. De Sutter J, De Backer J, Van de Veire N, Velghe A, De Buyzere M, Gillebert TC: Effects of age, gender, and left ventricular mass on septal mitral annulus velocity ( $\left.E^{\prime}\right)$ and the ratio of transmitral early peak velocity to E' (E/E'). Am J Cardiol 2005, 95: 1020-1023.

69. Prasad A, Okazaki K, Arbab-Zadeh AA, Dijk E, Fu Q, Thomas JD, Levine BD: Abnormalities of Doppler measures of diastolic function in the healthy elderly are not related to alterations of left atrial pressure. Circulation 2005, I I I:| |499-I503.

70. Remmen JJ, Aengevaeren WR, Verheugt FW, Jansen RW: Normal values of pulmonary capillary wedge pressure and the blood pressure response to the Valsalva manoeuvre in healthy elderly subjects. Clin Physiol Funct Imaging 2005, 25:318-326.

7I. Kitzman DW, Little WC, Brubaker PH, Anderson RT, Hundley WG, Marburger CT, Brosnihan B, Morgan TM, Stewart KP: Pathophysiological characterization of isolated diastolic heart failure in comparison to systolic heart failure. JAMA 2002, 288:2। $44-2 \mid 50$.
72. Wilson JR, Hanamanthu S, Chomsky DB, Davis SF: Relationship between exertional symptoms and functional capacity in patients with heart failure. J Am Coll Cardiol 1999, 33:1943-1947.

73. MacFadyen RJ, MacLeod CM, Shiels P, Russell Smith W, MacDonald TM: Isolated diastolic heart failure as a cause of breathlessness in the community: the Arbroath study. Eur J Heart Fail 200I, 3:243-248.

74. Pedersen F, Raymond I, Mehlsen J, Atar D, Hildebrandt PR: Prevalence of diastolic dysfunction as a possible cause of dyspnea in the elderly. Am J Med 2005, I I 8:25-3I.

75. Morrison LK, Harrison A, Krishnaswamy P, Kazanegra R, Clopton P, Maisel A: Utility of a rapid B-natriuretic peptide assay in differentiating congestive heart failure from lung disease in patients presenting with dyspnea. J Am Coll Cardiol 2002, 39:202-209.

76. Ha JW, Lulic F, Bailey KR, Pellikka PA, Seward JB, Tajik AJ, Oh JK: Effects of treadmill exercise on mitral inflow and annular velocities in healthy adults. Am J Cardiol 2003, 91 : I I4-II5.

77. Talreja $D$, Nishimura R, Oh J: Noninvasive parameters of diastolic function reflect invasively measured filling pressures during exercise [abstract]. Circulation 2004, I I 0(SuppI III):III-474.

78. Burgess MI, Jenkins C, Sharman JE, Marwik TH: Diastolic stress echocardiography: hemodynamic validation and clinical significance of estimation of ventricular filling pressure with exercise. J Am Coll Cardiol 2006, 47: $1891-1900$.

79. Matsumura Y, Elliott PM, Virdee MS, Sorajja P, Doi Y, McKenna WJ: Left ventricular diastolic function assessed using Doppler tissue imaging in patients with hypertrophic cardiomyopathy: relation to symptoms and exercise capacity. Heart 2002, 87:247-25I.

80. McMahon CJ, Nagueh SF, Pignatelli RH, Denfield SW, Dreyer WJ, Price JF, Clunie S, Bezold LY, Hay AL, Towbin JA, Eidem BW: Characterization of left ventricular diastolic function by tissue Doppler imaging and clinical status in children with hypertrophic cardiomyopathy. Circulation 2004, 109:1756-1762

8I. Ha JW, Cho JR, Kim JM, Ahn JA, Choi EY, Kang SM, Rim SJ, Chung N: Tissue Doppler-derived indices predict exercise capacity in patients with apical hypertrophic cardiomyopathy. Chest 2005, I 28:3428-3433.

82. Smart N, Haluska B, Leano R, Case C, Mottram PM, Marwik TH: Determinants of functional capacity in patients with chronic heart failure: role of filling pressure and systolic and diastolic function. Am Heart J 2005, I 49: I 52- I58.

83. Lee SH, Jung JH, Choi SH, Lee N, Oh DJ, Ryu KH, Rhim CY, Lee KH, Lee $Y$ : Exercise intolerance in patients with atrial fibrillation: clinical and echocardiographic determinants of exercise capacity. J Am Soc Echocardiogr 2005, 18:1349-1354.

84. Hadano Y, Murata K, Yamamoto T, Kunichika H, Matsumoto T, Akagawa E, Sato T, Tanaka T, Nose Y, Tanaka N, Matsuzaki M: Usefulness of mitral annular velocity in predicting exercise tolerance in patients with impaired left ventricular systolic function. Am J Cardiol 2006, 97: 1025-1028.

85. Van de Veire NR, De Winter O, Philippe J, De Buyzere M, Bernard D, Langlois M, Gillebert TC, De Suttere J: Maximum oxygen uptake at peak exercise in elderly patients with coronary artery disease and preserved left ventricular function The role of inflammation on top of tissue Doppler-derived systolic and diastolic function. Am Heart / 2006, I 52:297.el-e7.

86. Skaluba SJ, Litwin SE: Mechanisms of exercise intolerance. Insights from tissue Doppler imaging. Circulation 2004, 109:972-977.

87. Clark $A L$ : Origin of symptoms in chronic heart failure. Heart 2006, 92:12-16

88. Ha JW, Oh JK, Pellikka PA, Ommen SR, Stussy VL, Bailey KR, Seward JB, Tajik AJ: Diastolic stress echocardiography: a novel noninvasive diagnostic test for diastolic dysfunction using supine bicycle exercise Doppler echocardiography. J Am Soc Echocardiogr 2005, 18:63-68.

89. Steg PG, Joubin L, McCord J, Abraham WT, Hollander JE, Omland T, Mentre F, McCullough PA, Maisel AS: B-type natriuretic peptide and echocardiographic determination of ejection fraction in the diagnosis of congestive heart failure in patients with acute dyspnea. Chest 2005, I 28:2I-29.

90. Silver MA, Maisel A, Yancy CW, McCullough PA, Burnett JC Jr, Francis GS, Mehra MR, Peacock WF 4th, Fonarow G, Gibler WB, Morrow DA, Holland J: BNP consensus panel. BNP Consensus Panel 
2004: A clinical approach for the diagnostic, prognostic, screening, treatment monitoring, and therapeutic roles of natriuretic peptides in cardiovascular diseases. Congest Heart Fail 2004, I 0 (5 suppl 3): I-30.

91. Knudsen CW, Omland T, Clopton P, Westheim A, Wu AH, Duc P, McCord J, Nowak RM, Hollander JE, Storrow AB, Abraham WT, McCullough PA, Maisel A: Impact of atrial fibrillation on the diagnostic performance of B-type natriuretic peptide concentration in dyspneic patients: an analysis from the breathing not properly multinational study. J Am Coll Cardiol 2005, 46:838-844.

92. Yancy CW, Lopatin M, Stevenson LW, De Marco T, Fonarow GC: ADHERE Scientific Advisory Committee and Investigators. Clinical presentation, management, and in-hospital outcomes of patients admitted with acute decompensated heart failure with preserved systolic function: a report from the Acute Decompensated Heart Failure National Registry (ADHERE) Database. J Am Coll Cardiol 2006, 47:76-84.

93. Peacock WF IV, Fonarow GC, Emerman CL, Mills RM, Wynne J: Impact of early initiation of intravenous therapy for acute decompensated heart failure on outcomes in ADHERE. Cardiology 2006, 107:44-5I.

94. Logeart D, Saudubray C, Beyne P, Thabut G, Ennezat PV, Chavelas C, Zanker C, Bouvier E, Solal AC: Comparative value of Doppler echocardiography and B-type natriuretic peptide assay in the etiologic diagnosis of acute dyspnea. J Am Coll Cardiol 2002, 40:1794-1800.

95. Dabbah S, Reisner SA, Aronson D, Agmon Y: Left ventricular filling hemodynamics in patients with pulmonary edema and preserved versus reduced left ventricular ejection fraction: a prospective Doppler echocardiographic study. I Am Soc Echocardiogr 2006, 19:733-743.

96. Wang J, Kurrelmeyer KM, Torre-Amione G, Nagueh SF: Systolic and diastolic dyssynchrony in patients with diastolic heart failure and the effect of medical therapy. J Am Coll Cardiol 2007, 49:88-96.

97. Dokainish H, Zoghbi WA, Lakkis NM, Quinones MA, Nagueh SF: Comparative accuracy of $B$-type natriuretic peptide and tissue Doppler echocardiography in the diagnosis of congestive heart failure. Am / Cardiol 2004, 93: I I30- I I35.

98. Arques S, Roux E, Sbragia P, Ambrosi P, Taieb L, Pieri B, Gelisse R, Luccioni R: Accuracy of tissue Doppler echocardiography in the emergency diagnosis of decompensated heart failure with preserved left ventricular systolic function. Comparison with B-type natriuretic peptide measurement. Echocardiography 2005, 22:657-664.

99. Arques S, Roux E, Sbragia P, Pieri B, Gelisse R, Ambrosi P, Luccioni R: Accuracy of tissue Doppler echocardiography in the diagnosis of new-onset congestive heart failure in patients with levels of B-type natriuretic peptide in the mid-range and normal left ventricular ejection fraction. Echocardiography 2006, 23:627-634.

100. Arques S, Roux E, Sbragia P, Pieri B, Gelisse R, Luccioni R, Ambrosi $P$ : Usefulness of bedside tissue Doppler echocardiography and B-type natriuretic peptide (BNP) in differentiating congestive heart failure from noncardiac cause of acute dyspnea in elderly patients with a normal left ventricular ejection fraction and permanent, non-valvular atrial fibrillation: insights from a prospective, monocenter study. Echocardiography in press.

101. Knudsen CW, Omland T, Clopton P, Westheim A, Abraham WT, Storrow AB, McCord J, Nowak RM, Aumont MC, Duc P, Hollander JE, Wu AH, McCullough PA, Maisel A: Diagnostic value of B-type natriuretic peptide and chest radiographic findings in patients with acute dyspnea. Am J Med 2004, I I 6:363-368.

102. Strunk A, Bhalla V, Clopton P, Nowak RM, McCord J, Hollander JE, Duc P, Storrow AB, Abraham WT, Wu AH, Steg G, Perez A, Kazanegra R, Herrmann HC, Aumont MC, McCullough PA, Maisel A: Impact of the history of congestive heart failure on the utility of B-type natriuretic peptide in the emergency diagnosis of heart failure: results from the Breathing Not Properly Multinational Study. Am J Med 2006, I 1 9:69.el-el I.

103. Coste J, Jourdain P, Pouchot J: A gray zone assigned to inconclusive results of quantitative diagnostic tests: application to the use of brain natriuretic peptide for diagnosis of heart failure in acute dyspneic patients. Clin Chem 2006, 52:2229-2235.
104. Arques S, Roux E, Sbragia P, Gelisse R, Ambrosi P, Pieri B, Luccioni R: Comparative accuracy of color M-mode and tissue Doppler echocardiography in the emergency diagnosis of congestive heart failure in chronic hypertensive patients with normal left ventricular ejection fraction. $A m$ J Cardiol 2005, 96:1456-1459.

105. Huang CH, Tsai MS, Hsieh CC, Wang TD, Chang WT, Chen W]: Diagnostic accuracy of tissue Doppler echocardiography for patients with acute heart failure. Heart 2006, 92:1790-1794.
Publish with Bio Med Central and every scientist can read your work free of charge

"BioMed Central will be the most significant development for disseminating the results of biomedical research in our lifetime. "

Sir Paul Nurse, Cancer Research UK

Your research papers will be:

- available free of charge to the entire biomedical community

- peer reviewed and published immediately upon acceptance

- cited in PubMed and archived on PubMed Central

- yours - you keep the copyright

Submit your manuscript here:

http://www.biomedcentral.com/info/publishing_adv.asp 